\title{
Assessment of the potential for resistance to antimicrobial violet-blue light in Staphylococcus aureus
}

Rachael M. Tomb ${ }^{1 *}$, Michelle Maclean ${ }^{1,2}$, John E. Coia ${ }^{3}$, Scott J. MacGregor ${ }^{1}$ and John G. Anderson ${ }^{1}$

\begin{abstract}
Background: Antimicrobial violet-blue light in the region of $405 \mathrm{~nm}$ is emerging as an alternative technology for hospital decontamination and clinical treatment. The mechanism of action is the excitation of endogenous porphyrins within exposed microorganisms, resulting in ROS generation, oxidative damage and cell death. Although resistance to $405 \mathrm{~nm}$ light is not thought likely, little evidence has been published to support this. This study was designed to establish if there is potential for tolerance development, using the nosocomial pathogen Staphylococcus aureus as the model organism.

Methods: The first stage of this study investigated the potential for $S$. aureus to develop tolerance to high-intensity $405 \mathrm{~nm}$ light if pre-cultured in low-level stress violet-blue light $\left(\leq 1 \mathrm{~mW} / \mathrm{cm}^{2}\right)$ conditions. Secondly, the potential for tolerance development in bacteria subjected to repeated sub-lethal exposure was compared by carrying out 15 cycles of exposure to high-intensity $405 \mathrm{~nm}$ light, using a sub-lethal dose of $108 \mathrm{~J} / \mathrm{cm}^{2}$. Inactivation kinetics and antibiotic susceptibility were also compared.
\end{abstract}

Results: When cultured in low-level violet-blue light conditions, S. aureus required a greater dose of high-intensity $405 \mathrm{~nm}$ light for complete inactivation, however this did not increase with multiple (3) low-stress cultivations. Repeated sub-lethal exposures indicated no evidence of bacterial tolerance to $405 \mathrm{~nm}$ light. After 15 sub-lethal exposures 1.2 and $1.4 \log _{10}$ reductions were achieved for MSSA and MRSA respectively, which were not significantly different to the initial $1.3 \log _{10}$ reductions achieved $(P=0.242 \& 0.116$, respectively). Antibiotic susceptibility was unaffected, with the maximum change in zone of inhibition being $\pm 2 \mathrm{~mm}$.

Conclusions: Repeated sub-lethal exposure of non-proliferating S. aureus populations did not affect the susceptibility of the organism to $405 \mathrm{~nm}$ light, nor to antibiotics. Culture in low-level violet-blue light prior to $405 \mathrm{~nm}$ light exposure may increase oxidative stress responses in S. aureus, however, inactivation still occurs and results demonstrate that this is unlikely to be a selective process. These results demonstrate that tolerance from repeated exposure is unlikely to occur, and further supports the potential development of $405 \mathrm{~nm}$ light for clinical decontamination and treatment applications.

Keywords: 405 nm light, Bacterial tolerance, Bacterial resistance, Staphylococcus aureus, EMRSA-15

\footnotetext{
* Correspondence: rachael.tomb.2013@uni.strath.ac.uk

${ }^{1}$ The Robertson Trust Laboratory for Electronic Sterilisation Technologies (ROLEST), Department of Electronic \& Electrical Engineering, University of Strathclyde, Glasgow, UK

Full list of author information is available at the end of the article
} 


\section{Background}

There is global concern surrounding antibiotic resistant organisms, such as methicillin-resistant Staphylococcus aureus (MRSA). These organisms negatively impact on healthcare systems by causing infections which are harder to treat due to reduced antibiotic choices, resulting in longer hospital stays and increased mortality of patients [1]. To reduce transmission of these pathogenic organisms, new technologies are being developed to aid environmental decontamination and clinical treatment.

One such antimicrobial technology is $405 \mathrm{~nm}$ light. Violet-blue light in this region photo-excites intracellular porphyrins within microorganisms, producing a range of reactive oxygen species (ROS) which cause oxidative damage and cell death [2-4]. Although less germicidal than ultraviolet (UV) light, $405 \mathrm{~nm}$ light has broad-spectrum antimicrobial action against Gram positive and negative bacteria, bacterial biofilms, endospores, yeasts, fungi and in some circumstances viruses [5-11]. When used at appropriate irradiances, these wavelengths of visible light can also exert antimicrobial effects whilst being nondetrimental to mammalian cells [12-14], giving it operational advantages over UV-light for applications such as continuous decontamination of occupied environments [15-18] and wound decontamination [12]. Additionally, it has recently been reported that $405 \mathrm{~nm}$ light can also have a synergistic antimicrobial effect with common chlorinated disinfectants, providing further support for its beneficial use for environmental decontamination [19].

Although $405 \mathrm{~nm}$ light has extensive antimicrobial action and safety advantages, little is known about the potential for the development of bacterial resistance or tolerance to violet-blue $405 \mathrm{~nm}$ light inactivation. It is hypothesised that tolerance is unlikely due to the mechanism of inactivation $[13,17,20]$. Similar to that of photodynamic inactivation (PDI), which makes use of an additional photosensitizer, the mechanism of inactivation is thought to be non-selective, as the ROS and ${ }^{1} \mathrm{O}_{2}$ produced cause unspecific damage to a wide spectrum of targets within bacterial cells [13, 17, 20, 21]. Nevertheless there is little evidence available to support this hypothesis. Several studies have investigated tolerance formation following repeated PDI in a range of microorganisms including methicillin-sensitive and methicillin-resistant $S$. aureus, Escherichia coli, Pseudomonas aeruginosa, Peptostreptococcus micros, Actinobacillus actinomycetes and Vibrio fischeri, in which none of the aforementioned species were found to become tolerant [21-25]. However little is known about the potential for bacterial tolerance development to antimicrobial $405 \mathrm{~nm}$ light alone.

This study was carried out to determine if there is potential for tolerance development in exposed organisms, using the nosocomial pathogen $S$. aureus as the model organism. The first stage of the study assessed whether pre- culture in low-level light-stress conditions would subsequently affect the susceptibility of the organism to $405 \mathrm{~nm}$ light inactivation and increase tolerance. Secondly, the study investigated the effect of repeated sub-lethal exposure to high-intensity $405 \mathrm{~nm}$ light on methicillin-sensitive and methicillin-resistant $S$. aureus, with the number of sub-lethal exposures being extended past those carried out in previously published studies [20, 26, 27]. To further investigate the likelihood of tolerance, the inactivation kinetics and antibiotic susceptibility of survivors after sublethal exposure were analysed and compared. The results provide novel fundamental evidence to support the hypothesis that tolerance following repeated exposure to $405 \mathrm{~nm}$ light is unlikely in both proliferating and nonproliferating bacteria.

\section{Methods}

\section{Microorganisms}

Two strains of Staphylococcus aureus were used in this study, methicillin-sensitive S. aureus NCTC 4135 (National Collection of Type Cultures, Collindale, UK) and epidemic methicillin-resistant S. aureus-15 (EMRSA-15) (Scottish Reference Laboratory, Glasgow, UK), which are referred to as MSSA and MRSA throughout the study.

\section{Determining potential for tolerance development when cultured under different lighting conditions Cultivation in different lighting conditions}

MSSA was inoculated in $100 \mathrm{ml}$ nutrient broth (NB; Oxoid, UK) and cultivated under different lighting conditions: (i) complete darkness (flasks wrapped in aluminium foil); (ii) normal laboratory fluorescent lighting, approximately 200 Lux (measured using a Light Level Meter; Labfacility, UK); and (iii) 3 levels of low-intensity $405 \mathrm{~nm}$ light: 0.15, 0.5 \& $1 \mathrm{~mW} / \mathrm{cm}^{2}$ (measured using a radiant power meter and photodiode detector (LOT Oriel, USA)). The light source used was a low-power matrix of 9-light emitting diode arrays (LED) (GE Illumination, USA) with a peak wavelength in the region of $405 \mathrm{~nm}$ and a full width at half maximum (FWHM) of approximately $18 \mathrm{~nm}$ (Fig. 1). Arrays were arranged in a $3 \times 3$ grid pattern on a heat sink (for heat dissipation), and powered by a variable DC power supply (Velleman, Belgium). The light source and power supply were placed in the $37{ }^{\circ} \mathrm{C}$ incubator, $30 \mathrm{~cm}$ from the cultivation flask, and allowed to stabilise before setting the irradiance; this ensured that the current would not fluctuate during temperature increase. Utilising this light source enabled low level illumination of a large surface area (culture flask) during bacterial cultivation. Bacteria were cultured in these lighting conditions under rotary incubation (120 rpm) at $37{ }^{\circ} \mathrm{C}$ for $18-24 \mathrm{~h}$. The broths were then centrifuged at $3939 \times g$ for $10 \mathrm{~min}$ and the pellets re-suspended in $100 \mathrm{ml}$ phosphate buffer saline (PBS; Oxoid, UK). Bacterial suspensions were then diluted in PBS to an experimental starting 


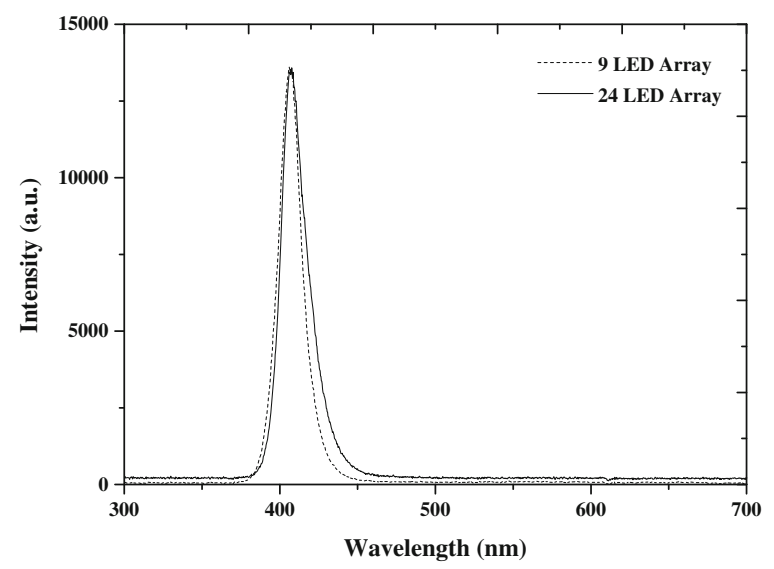

Fig. 1 Optical emission spectrum of the 9-LED and 24-LED $405 \mathrm{~nm}$ arrays. Measured using an HR4000 spectrometer (Ocean Optics, Germany) and Spectra Suite software version 2.0.151

population of $1-2 \times 10^{5} \mathrm{CFU} / \mathrm{ml}$ for exposure to highirradiance $405 \mathrm{~nm}$ light.

\section{Exposure to high-irradiance $405 \mathrm{~nm}$ light following cultivation under different lighting conditions}

Following cultivation in the different lighting conditions, the bacteria where exposed to high-irradiance $405 \mathrm{~nm}$ light to establish if their susceptibility to $405 \mathrm{~nm}$ light had been affected. The high-power light source used for exposure was a 24-LED array (PhotonStar Technologies, UK) with peak wavelength in the region of $405 \mathrm{~nm}$ and 19 nm FWHM (Fig. 1). The source was connected to a heat sink and cooling fan for heat dissipation, and was powered by a $40 \mathrm{~V}$ Xitanium LED Driver (Phillips, Netherlands). This light source provided high-intensity illumination over a small surface area, ideal for exposure of samples in 6-well plates.

The array was held in a PVC housing approximately $6 \mathrm{~cm}$ above the surface of the bacterial samples. Five millileters bacterial samples were exposed to $405 \mathrm{~nm}$ light at an irradiance of $60 \mathrm{~mW} / \mathrm{cm}^{2}$, with sample plates positioned on a magnetic stirring plate to permit constant agitation. Control plates were held under identical conditions however only subjected to normal laboratory lighting. Samples were exposed to increasing doses of light, with dose $\left(\mathrm{J} / \mathrm{cm}^{2}\right)$ calculated as irradiance (W/ $\mathrm{cm}^{2}$ ) $\times$ exposure time (s). During exposure, samples were taken at $15 \mathrm{~min}$ intervals and plated onto nutrient agar (NA; Oxoid, UK). Plates were incubated at $37{ }^{\circ} \mathrm{C}$ for $24 \mathrm{~h}$ and then enumerated, with results reported as colony forming units per millilitre $(\mathrm{CFU} / \mathrm{ml})$ as a function of dose $\left(\mathrm{J} / \mathrm{cm}^{2}\right)$.

Investigating the minimum inhibitory concentration of $\mathrm{H}_{2} \mathrm{O}_{2}$ To investigate if there were any intracellular changes in catalase production following growth in low-level violet- blue light, a minimum inhibitory concentration (MIC) assay of hydrogen peroxide $\left(\mathrm{H}_{2} \mathrm{O}_{2}\right)$ was performed. This was based upon methodology used by Lipovsky et al. [28]. Briefly, following 4-5 h of cultivation in fluorescent laboratory lighting, complete darkness or $1 \mathrm{~mW} / \mathrm{cm}^{2}$ $405 \mathrm{~nm}$ light, $100 \mu \mathrm{l}$ of MSSA $\left(10^{6} \mathrm{CFU} / \mathrm{ml}\right)$ was added to two-fold dilutions of $\mathrm{H}_{2} \mathrm{O}_{2}$ in NB. The $\mathrm{H}_{2} \mathrm{O}_{2}$ dilutions were then incubated at $37{ }^{\circ} \mathrm{C}$ for $24 \mathrm{~h}$ and the MIC identified as the lowest concentration of $\mathrm{H}_{2} \mathrm{O}_{2}$ which caused visible inhibition of bacterial growth.

\section{Carotenoid (Staphyloxanthin) extraction}

To investigate if carotenoid pigments protected $S$. aureus against singlet oxygen stress during growth in lowlevel violet-blue light, carotenoid content was measured. Carotenoid extraction was adapted from that used by Bartolomeu et al. [25]. MSSA was cultured in fluorescent laboratory lighting, complete darkness or $1 \mathrm{~mW} /$ $\mathrm{cm}^{2} 405 \mathrm{~nm}$ light for $24 \mathrm{~h}$. After cultivation the cultures were washed thrice in sterile $\mathrm{H}_{2} \mathrm{O}$, re-suspended in $5 \mathrm{ml}$ 99.9\% methanol, and incubated in a $55{ }^{\circ} \mathrm{C}$ water bath for 15 mins until the cells had been bleached. Following extraction, the samples were centrifuged at $8000 \times g$ for $10 \mathrm{~min}$. The supernatant was removed and recentrifuged at $10,000 \times g$ for 15 mins to ensure removal of any residual biomass. The carotenoid content was then measured by recording the absorbance at $465 \mathrm{~nm}$ in a quartz cuvette, using a Biomate 5 Spectrophotometer (Thermo Fischer Scientific, UK).

\section{Determining potential for tolerance development following repeated sub-lethal exposure to high-intensity $405 \mathrm{~nm}$ light \\ Repeated sub-lethal exposure}

MSSA and MRSA were inoculated, in triplicate, in $100 \mathrm{ml}$ $\mathrm{NB}$, and cultivated at $37^{\circ} \mathrm{C}$ for $18-24$ h under rotary conditions $(120 \mathrm{rpm})$ in the dark. Cultures were re-suspended in PBS and diluted to a $10^{5} \mathrm{CFU} / \mathrm{ml}$ population. Bacterial samples were then exposed to $405 \mathrm{~nm}$ light at a dose of $108 \mathrm{~J} / \mathrm{cm}^{2}\left(60 \mathrm{~mW} / \mathrm{cm}^{2}\right.$ for $\left.30 \mathrm{~min}\right)$ using the highintensity 24-LED array (as described in earlier section 'Exposure to High-Irradiance $405 \mathrm{~nm}$ Light Following Cultivation under Different Lighting Conditions').

Following exposure, samples were plated onto NA and incubated at $37{ }^{\circ} \mathrm{C}$ for $24 \mathrm{~h}$. Surviving colonies were enumerated and termed as survivors from 'Run 1 '. Surviving colonies from 'Run 1' were then used to inoculate $\mathrm{NB}$, in triplicate, and the above process of exposure-subculture-exposure was repeated until 15 sub-lethal exposures had occurred (Fig. 2). Survivors from each run were tested using Staphaurex Plus Latex Agglutination (Thermo Fischer Scientific, UK) and Penicillin Binding Protein (PBP2') Latex (Oxoid, UK) to ensure no contamination had occurred. This 


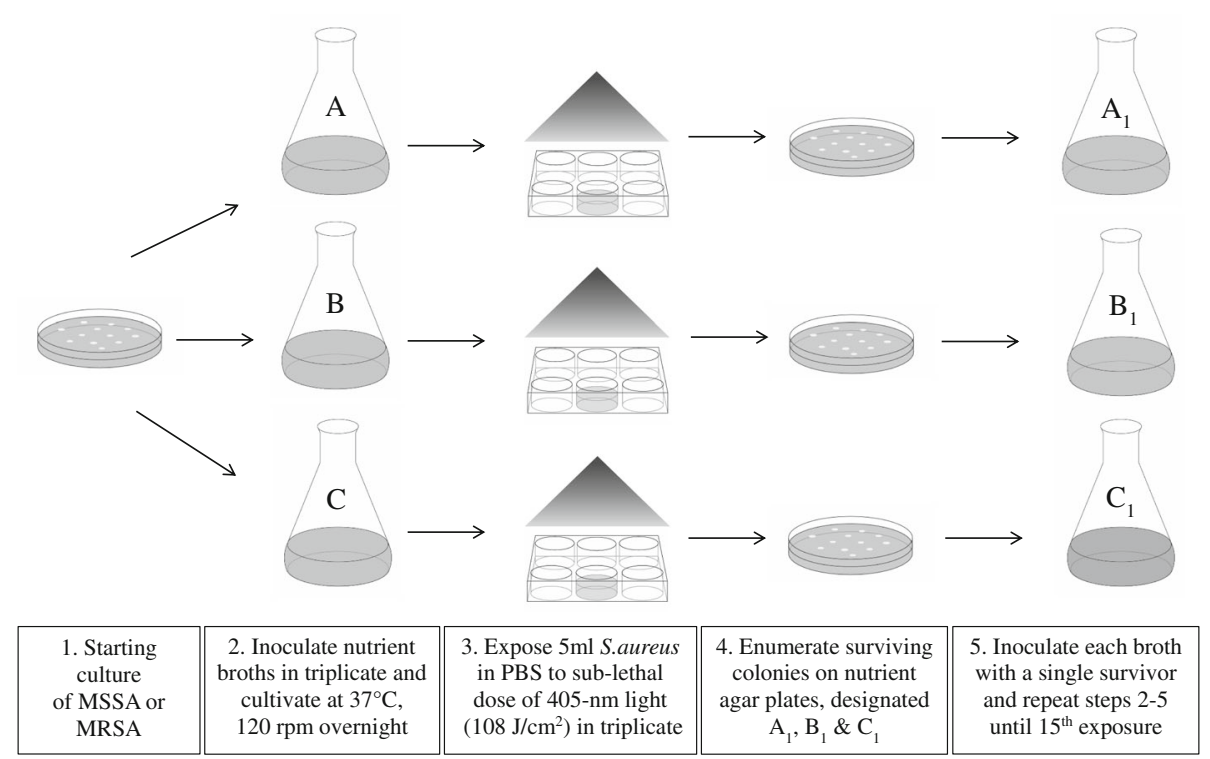

Fig. 2 Flow diagram of the experimental procedure used during repeated sub-lethal $405 \mathrm{~nm}$ light exposure. Methicillin-sensitive Staphylococcus aureus (MSSA) and methicillin-resistant Staphylococcus aureus (MRSA) were exposed to 15 cycles of a dose of $108 \mathrm{~J} / \mathrm{cm}^{2}$, at an irradiance of $60 \mathrm{~mW} / \mathrm{cm}^{2}$

was based on the principle that if the Staphaurex test gave a negative result, then this would indicate that the surviving isolate was not the test organism and that contamination by a rogue organism had occurred. If however, the isolate gave a positive Staphaurex result but a negative PBP2' result, then this would indicate that the MRSA cultures were likely contaminated with MSSA or that MRSA had lost the ability to produce PBP2' following exposure to $405 \mathrm{~nm}$ light.

\section{Inactivation kinetics of survivors following sub-lethal exposure}

Full inactivation kinetics were also established out using the initial cultures and survivors after 5, 10 and 15 sublethal exposures. These isolates were cultivated in $100 \mathrm{ml} \mathrm{NB}$ in the dark and exposed to $60 \mathrm{~mW} / \mathrm{cm}^{2}$ $405 \mathrm{~nm}$ light, with samples taken every $15 \mathrm{~min}$ for 75 mins and 90 mins for MSSA and MRSA respectively (as described in earlier section 'Exposure to High-Irradiance $405 \mathrm{~nm}$ Light Following Cultivation under Different Lighting Conditions').

\section{Antibiotic susceptibility testing}

Antibiotic susceptibility testing was carried out following the EUCAST guidelines [29] as closely as possible (variations included the use of $90 \mathrm{~mm}$ plates, stacking during incubation, and inoculation with only one antibiotic disc/plate to prevent overlap if bacterial susceptibility increased). The antibiotics used were chloramphenicol, ciprofloxacin, erythromycin, fusidic acid, gentamicin, mupirocin, oxacillin, rifampicin, tetracycline and vancomycin. These 10 were selected as they represented antibiotics, with differing antimicrobial mechanisms, which are recommended clinical treatment options for Staphylococcus aureus infections. Fresh bacterial cultures were diluted to a $10^{8} \mathrm{CFU} / \mathrm{ml}$ population, spread onto mueller-hinton $(\mathrm{MH})$ agar plates (Oxoid, UK) using sterile swabs and a single antibiotic disc (Mast Group, UK) placed into the centre of the plate. The plates were immediately incubated at $35 \pm 2{ }^{\circ} \mathrm{C}$ for $18-20 \mathrm{~h}$ after which the diameter of the zone of inhibition was measured in normal laboratory lighting and recorded to the nearest $\mathrm{mm}$.

\section{Data analysis}

Data represents mean results \pm standard deviation (SD), taken from triplicate independent experiments, measured in at least duplicate for $405 \mathrm{~nm}$ light inactivation experiments $(n \geq 6)$. As samples were directly plated onto NA plates, some samples counted were below the detection limit $(25 \mathrm{CFU} / \mathrm{ml})$ however these have been included in graphs to demonstrate the near-to-complete inactivation effect achieved. Repeated sub-lethal exposure results are reported as bacterial inactivation efficiency $\left(\log _{10} N_{O} / N\right)$, with $N$ representing the light-exposed population, and $N_{O}$ the equivalent non-exposed control population. Significant differences were calculated using Two-Sample T-Tests or One-way ANOVA with Dunnett's post-hoc test (Minitab 17 Statistical Software), with results found to be significant when $P \leq 0.05$. 


\section{Results}

Determining potential for tolerance development when cultured under different lighting conditions Bacterial inactivation kinetics following single culture The first stage of the study investigated $405 \mathrm{~nm}$ light susceptibility of methicillin-sensitive S. aureus (MSSA) following growth in different lighting conditions. As shown in Fig. 3, relatively linear inactivation kinetics were demonstrated for both MSSA cultivated in fluorescent laboratory light (white light) and in complete darkness, with $5 \log _{10}$ reductions achieved after a final dose of $216 \mathrm{~J} / \mathrm{cm}^{2} 405 \mathrm{~nm}$ light. No significant differences in inactivation between MSSA cultures cultivated in fluorescent laboratory light or in complete darkness were detected at any of the tested sampling points using a TwoSample t-Test $(P \geq 0.05)$. No significant change was seen in the equivalent non-exposed controls $(P=0.932 \&$ 0.747 for light and dark cultures, respectively).

When cultured under low-intensity $405 \mathrm{~nm}$ light, some slight differences in the inactivation kinetics were observed. Although trends appeared similar (Fig. 4), differences in the susceptibility of bacteria cultured in lowintensity $405 \mathrm{~nm}$ light versus dark cultured can be seen at certain points during the experiment. Following exposure to 108 and $162 \mathrm{~J} / \mathrm{cm}^{2}$ high-intensity $405 \mathrm{~nm}$ light, MSSA cultured in $0.15,0.5$ and $1 \mathrm{~mW} / \mathrm{cm}^{2}$ $405 \mathrm{~nm}$ light showed significantly less inactivation than that cultured in complete darkness $(P<0.05)$. By a final dose of $216 \mathrm{~J} / \mathrm{cm}^{2}$, the inactivation achieved between the dark cultured and low-irradiance $405 \mathrm{~nm}$ light cultured MSSA was similar ( 4-5 $\log _{10}$ reduction), with the

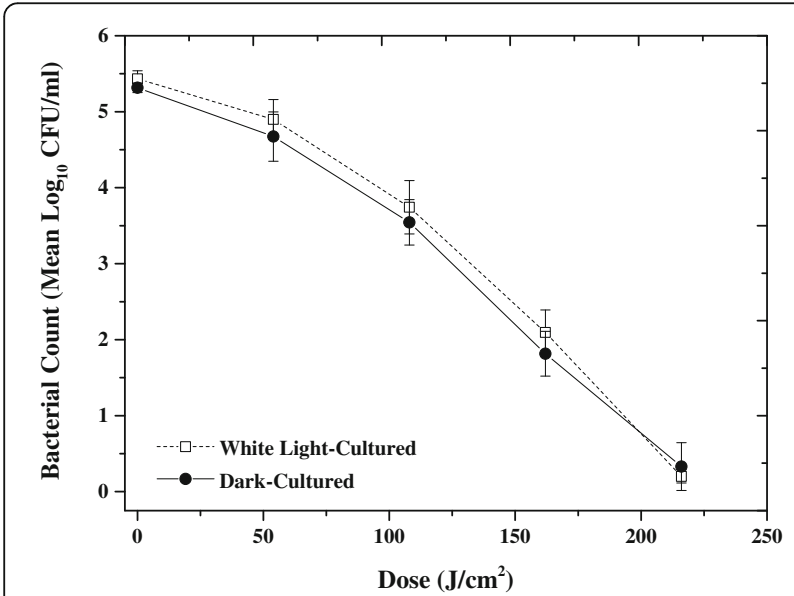

Fig. 3 Inactivation of MSSA following culture in white light or complete darkness. Methicillin-sensitive Staphylococcus aureus (MSSA) was inactivated following exposure to $60 \mathrm{~mW} / \mathrm{cm}^{2} 405 \mathrm{~nm}$ light after culture in fluorescent laboratory lighting (white light) or complete darkness. Each data point is a mean value \pm SD $(n \geq 6)$. No significant differences were found between the susceptibility of the light and dark cultured MSSA, using two-sample t-Test $(P \geq 0.05)$. No significant changes were observed in the final control populations $(P \geq 0.05)$

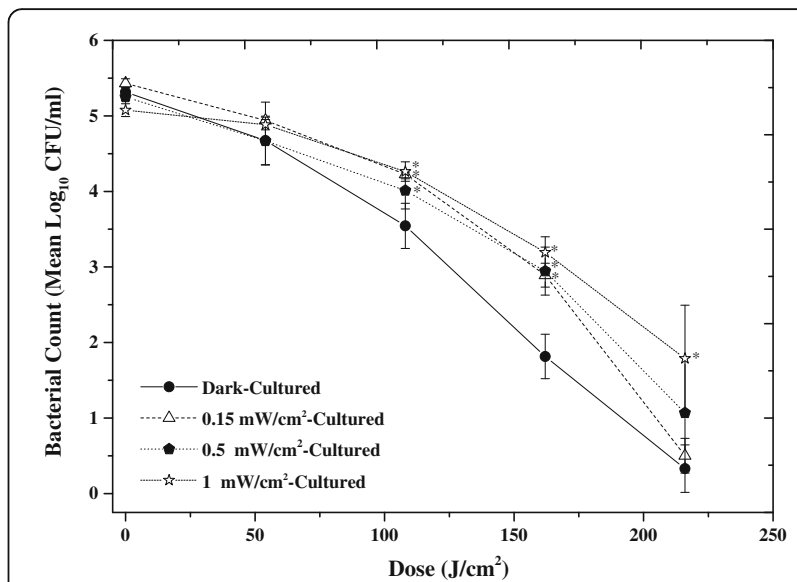

Fig. 4 Inactivation of MSSA following overnight culture in low-level $405 \mathrm{~nm}$ light. Methicillin-sensitive Staphylococcus aureus (MSSA) was inactivated following exposure to $60 \mathrm{~mW} / \mathrm{cm}^{2} 405 \mathrm{~nm}$ light after overnight culture in low-level $405 \mathrm{~nm}$ light $\left(0.15,0.5\right.$ and $\left.1 \mathrm{~mW} / \mathrm{cm}^{2}\right)$. The inactivation kinetics of dark-cultured MSSA have been included for reference. Each data point is a mean value $\pm S D(n \geq 6)$. * Indicates $405 \mathrm{~nm}$ light-cultured samples that were significantly different to those which had been dark-cultured, using one way ANOVA with Dunnett's post-hoc test $(P<0.05)$. No significant changes were observed in the final control populations $(P \geq 0.05)$

exception of the MSSA cultured in $1 \mathrm{~mW} / \mathrm{cm}^{2} 405 \mathrm{~nm}$ light: when cultured under this lighting condition, only $3.3 \log _{10}$ reduction was achieved compared to $5 \log _{10}$ reduction for dark-cultivated MSSA $(P=0.045)$. No significant change was seen in the equivalent non-exposed controls $(P=1.00,0.268 \& 0.744$ for $0.15,0.5$ and $1 \mathrm{~mW} / \mathrm{cm}^{2}$ cultures, respectively).

Investigating the minimum inhibitory concentration of $\mathrm{H}_{2} \mathrm{O}_{2}$ Table 1 shows that the average $\mathrm{MIC}$ of $\mathrm{H}_{2} \mathrm{O}_{2}$ is significantly higher for MSSA cultured in $1 \mathrm{~mW} / \mathrm{cm}^{2} 405 \mathrm{~nm}$ light $(P=0.011)$ compared to when cultured in white light $(P=0.044)$ or complete darkness $(P=0.024)$.

Table 1 Minimum Inhibitory Concentration of $\mathrm{H}_{2} \mathrm{O}_{2}$ and carotenoid content of Staphylococcus aureus following different culture conditions

\begin{tabular}{lll}
\hline Growth Conditions & $\begin{array}{l}\text { Average Minimum } \\
\text { Inhibitory Concentration } \\
\text { of } \mathrm{H}_{2} \mathrm{O}_{2}(\%) \pm \mathrm{SD}\end{array}$ & $\begin{array}{l}\text { Average Carotenoid } \\
\text { Absorbance } \\
\text { at } 465 \mathrm{~nm} \pm \mathrm{SD}\end{array}$ \\
\hline Complete Darkness & $0.00293 \pm 0.00000$ & $0.90 \pm 0.22$ \\
White Lighting & $0.00513 \pm 0.00146$ & $0.82 \pm 0.24$ \\
Low irradiance & $0.01831 \pm 0.01025^{*}$ & $0.17 \pm 0.12^{*}$ \\
$\left(1 \mathrm{~mW} / \mathrm{cm}^{2}\right)$ & & \\
$405 \mathrm{~nm}$ Light & &
\end{tabular}

Differences in the minimum inhibitory concentration (MIC) of hydrogen peroxide $\left(\mathrm{H}_{2} \mathrm{O}_{2}\right)$ and carotenoid content of methicillin-sensitive Staphylococcus aureus when cultivated in different lighting conditions. Data points represent the mean count $(n=3) \pm$ SD

"represents a significant change $(P<0.05)$ 


\section{Carotenoid (Staphyloxanthin) extraction}

Results shown in Table 1 demonstrate that the presence of the carotenoid staphyloxanthin is significantly lower in MSSA cultured in $1 \mathrm{~mW} / \mathrm{cm}^{2} 405 \mathrm{~nm}$ light $(P=0.009)$ compared to that grown in white light $(P=0.015)$ or complete darkness $(P=0.008)$.

\section{Bacterial inactivation kinetics following multiple cultures}

MSSA was grown in $1 \mathrm{~mW} / \mathrm{cm}^{2} 405 \mathrm{~nm}$ light, subcultured onto NA plates, then re-cultured in (a) complete darkness once or (b) $1 \mathrm{~mW} / \mathrm{cm}^{2}$ a further two more times. As can be seen in Fig. $5 \mathrm{a}$, when cultivated in $1 \mathrm{~mW} / \mathrm{cm}^{2}$ followed by cultivation in complete darkness, the level of inactivation returns to that of cultivation in darkness alone, with no significant difference in the level of inactivation $(P=0.395)$, and similarly the level of inactivation was significantly greater than that of MSSA grown in $1 \mathrm{~mW} / \mathrm{cm}^{2}$ $405 \mathrm{~nm}$ light $(P=0.043)$. No significant change was seen in the equivalent non-exposed controls $(P=0.505)$. Figure $5 \mathrm{~b}$ also demonstrates that triplicate cultivation in $1 \mathrm{~mW} / \mathrm{cm}^{2}$ does not select for more tolerant cultures. The sensitivity of MSSA to high-intensity $405 \mathrm{~nm}$ light returns to a similar level of that when cultivated in complete darkness alone, with an average $0.7 \times 10^{1} \mathrm{CFU} / \mathrm{ml}$ population surviving following a dose of $216 \mathrm{~J} / \mathrm{cm}^{2}$, which is not significantly different to the average $0.3 \times 10^{1} \mathrm{CFU} / \mathrm{ml}$ surviving population which had been grown in darkness $(P=0.230)$. No significant change was seen in the equivalent non-exposed controls $(P=0.338)$.

\section{Determining potential for tolerance development following repeated sub-lethal exposure to high-intensity $405 \mathrm{~nm}$ light \\ Repeated sub-lethal exposure}

The next stage of this study was to investigate the likelihood of tolerance development when non-proliferating Staphylococcus aureus was repeatedly exposed to a sublethal dose of high-intensity $405 \mathrm{~nm}$ light A dose of $108 \mathrm{~J} /$ $\mathrm{cm}^{2}$ was selected for use, as this had been shown to cause approximately $98 \%\left(1.6-1.8 \log _{10}\right)$ inactivation of the organism (Figs. 3 and 4). As can be seen from Fig. 6a, after repeated sub-lethal exposure there were fluctuations in MSSA inactivation, with the maximum inactivation seen after 7 sub-lethal exposures $\left(1.5 \log _{10}\right.$ reduction) and minimum after 4 sub-lethal exposures $\left(1.1 \log _{10}\right.$ reduction). However there was no significant difference $(P=0.242)$ in MSSA inactivation, compared to equivalent non-exposed controls, after 1 sub-lethal exposure compared to those after 15 sub-lethal exposures, with $1.3 \log _{10}$ and $1.2 \log _{10}$ inactivation achieved respectively. Additionally, one-way ANOVA and Dunnett's post-hoc analysis, using Run 1 as the control group, indicated that there was no significant difference in the bactericidal efficiency of $405 \mathrm{~nm}$ light $\left(\log _{10} N_{0} / N\right)$ between the sub-lethal
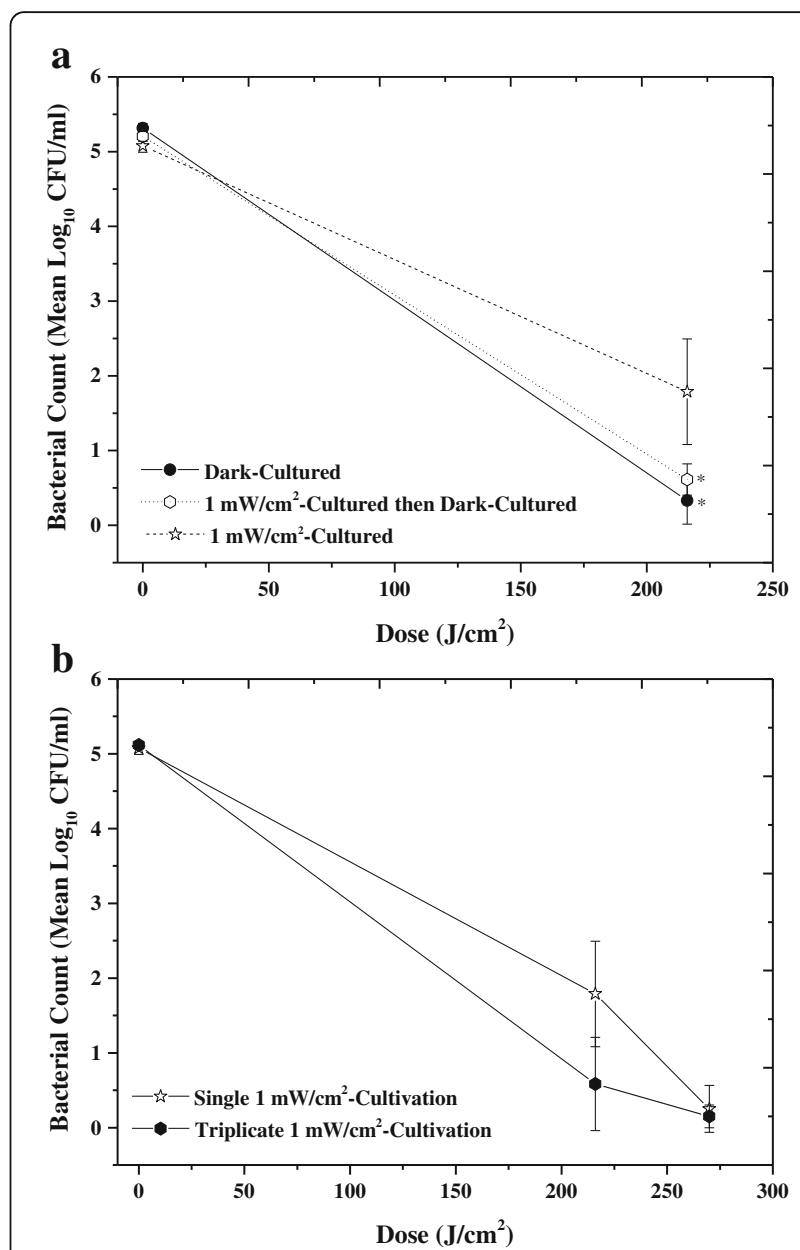

Fig. 5 Comparison of MSSA susceptibility to high-intensity $405 \mathrm{~nm}$ light after cultivation in different lighting conditions. a Methicillin-sensitive Staphylococcus aureus (MSSA) was cultivated in low-intensity $\left(1 \mathrm{~mW} / \mathrm{cm}^{2}\right)$ $405 \mathrm{~nm}$ light followed by cultivation in complete darkness, and $\mathbf{b}$ MSSA was subjected to repeated (three times) cultivation in low-intensity $\left(1 \mathrm{~mW} / \mathrm{cm}^{2}\right) 405 \mathrm{~nm}$ light. Each cultivation was at $37^{\circ} \mathrm{C}$ for $18 \mathrm{~h}$. Following these cultivation conditions, bacteria were exposed to increasing doses of high-intensity $60 \mathrm{~mW} / \mathrm{cm}^{2}$ light to establish the inactivation kinetics. Inactivation kinetics of bacteria which had been pre-cultured once in darkness or low-intensity $405 \mathrm{~nm}$ light are given as a comparison. * Indicates cultured samples that were significantly different to those which had been cultured once in $1 \mathrm{~mW} / \mathrm{cm}^{2} 405 \mathrm{~nm}$ light, using one way ANOVA with Dunnett's post-hoc test $(P<0.05)$. Each data point is a mean value $\pm S D(n \geq 6)$. No significant changes were observed in the final control populations $(P \geq 0.05)$

exposures. No significant change was seen in the equivalent non-exposed controls $(P=0.198)$.

As a comparison a clinical isolate of MRSA was also repeatedly exposed to sub-lethal levels of $405 \mathrm{~nm}$ light. Figure $6 \mathrm{~b}$ demonstrates that similarly to MSSA, there were fluctuations in inactivation of MRSA, with a maximum inactivation after 14 sub-lethal exposures ( $1.8 \log _{10}$ reduction) and minimum after 10 sub-lethal exposures $\left(1.1 \log _{10}\right.$ reduction). Furthermore there was also no significant difference $(P=0.943)$ between the $1.3 \log _{10}$ and $1.4 \log _{10}$ 


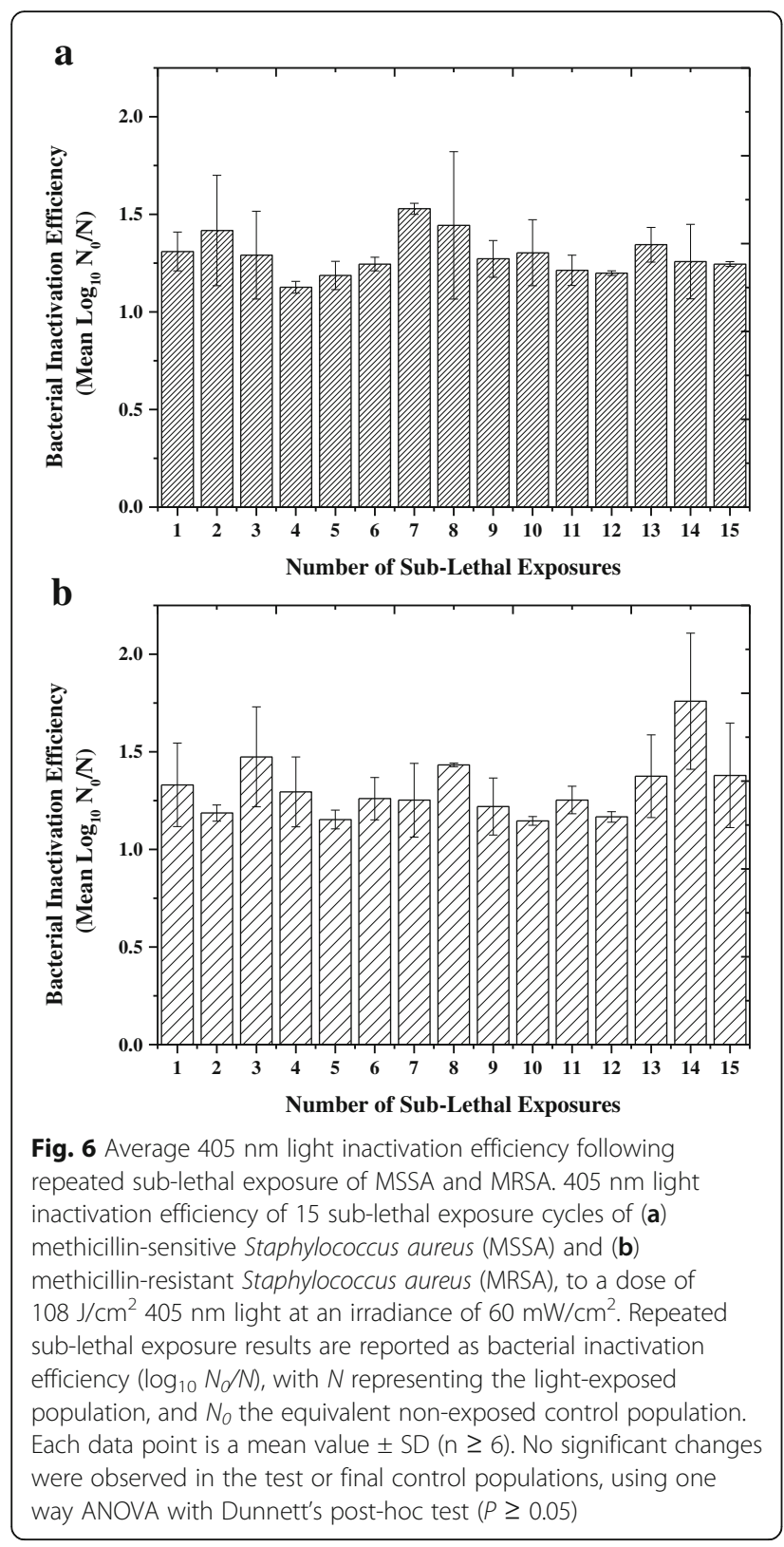

reduction after 1 and 15 sub-lethal exposures respectively. Similarly to MSSA, one-way ANOVA and Dunnett's posthoc analysis, using Run 1 as the control group, indicated that there was no significant difference in the bactericidal efficiency of $405 \mathrm{~nm}$ light $\left(\log _{10} N_{0} / N\right)$ between the sublethal exposures. No significant change was seen in the equivalent non-exposed controls $(P=0.116)$.

\section{Inactivation kinetics of survivors following sub-lethal exposure}

The inactivation kinetics of surviving MSSA and MRSA isolates after 5, 10 and 15 sub-lethal exposures to $60 \mathrm{~mW} /$ $\mathrm{cm}^{2}$ light were also determined. Figure 7a shows that after a dose of $270 \mathrm{~J} / \mathrm{cm}^{2}$ (75 mins) there was no significant difference in the level of MSSA inactivation after 5, 10 and 15
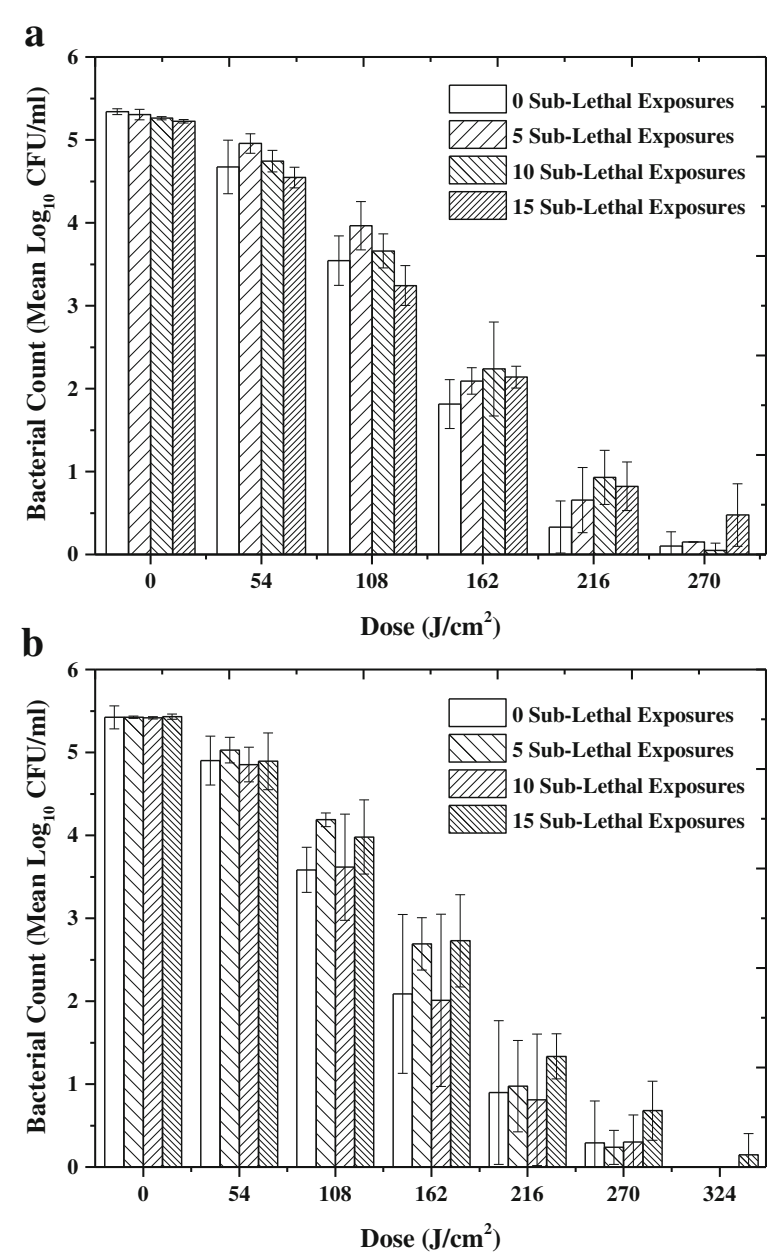

Fig. 7 Average inactivation kinetics of MSSA and MSSA after repeated sub-lethal exposures of $405 \mathrm{~nm}$ light. Inactivation kinetics of isolates of (a) methicillin-sensitive Staphylococcus aureus (MSSA) and (b) methicillin-resistant Staphylococcus aureus (MRSA) after 5, 10 and 15 sub-lethal exposures of $405 \mathrm{~nm}$ light. Sub-lethal exposures were conducted using a dose of $108 \mathrm{~J} / \mathrm{cm}^{2}$ (at an irradiance of $60 \mathrm{~mW} / \mathrm{cm}^{2}$ ), and inactivation kinetics were based on exposure to $60 \mathrm{~mW} / \mathrm{cm}^{2}$ for increasing time periods. Results are compared to non-sub-lethally exposed bacteria as a control. Each data point is a mean value $\pm S D(n \geq 6)$. No significant changes were observed in the test populations, using one way ANOVA with Dunnett's post-hoc test $(P \geq 0.05)$

sub-lethal exposures, with $5.2(P=0.895), 5.2(P=0.795)$ and $4.8(P=0.583) \log _{10}$ reduction achieved, compared to non-sub-lethally exposed MSSA. Similarly, MRSA showed no significant difference in inactivation after a dose of $324 \mathrm{~J} / \mathrm{cm}^{2}$ (90 mins) with $5.4(P=0.193), 5.4(P=0.259)$ and $5.3(P=0.081) \log _{10}$ reductions of MRSA after 5,10 and 15 sub-lethal exposures, respectively.

\section{Antibiotic susceptibility testing}

Although little change was seen in bacterial susceptibility to high-intensity $405 \mathrm{~nm}$ light after repeated sub-lethal exposure, antibiotic susceptibility was also investigated. 
Table 2 shows that there was little variation in the diameter of the zones of inhibition for MSSA after 5, 10 and 15 sub-lethal exposures compared to the initial non sublethally exposed populations. There were no significant decreases in the diameter of the zone of inhibition between the initial non sub-lethally exposed MSSA and survivors of 15 sub-lethal exposures $(P>0.05)$. There was a slight decrease in the average diameter of the zone of inhibition caused by mupirocin after 5 sub-lethal exposures, however after 10 and 15 sub-lethal exposures inhibition was comparable to non-stressed cultures $(P>0.05)$.

With regards to the antibiotic susceptibility of MRSA isolates after sub-lethal exposure, there were no significant decreases between the initial non-sub-lethally exposed populations and those after 15 sub-lethal exposures.

Interestingly there were significant increases in the diameter of the zone of inhibition for fusidic acid after 10 sub-lethal exposures and rifampicin after 15 sublethal exposures for MSSA and with gentamicin after 15 sub-lethal exposures for MRSA, compared to initial non sub-lethally exposed populations.

\section{Discussion}

This study has addressed the question of the potential for $S$. aureus to become tolerant to antimicrobial $405 \mathrm{~nm}$ violet-blue light and has provided new information under carefully controlled experimental test conditions.

The results from the first stage of the study, demonstrated that MSSA cultured in $1 \mathrm{~mW} / \mathrm{cm}^{2} 405 \mathrm{~nm}$ light appeared to exhibit a degree of tolerance to highintensity $405 \mathrm{~nm}$ light, compared to when dark-cultured. This suggests that exposure to low-intensity $405 \mathrm{~nm}$ light during culture may have acted as a low-level stressor during growth, which could have increased the up- regulation of bacterial oxidative stress responses. Bacteria have developed several mechanisms to overcome oxidative stress, including enzymes to detoxify reactive oxygen species such as catalase, peroxidase and superoxide dismutase [30]. To detect changes in the ability of MSSA to tolerate oxidative stress after culture in the presence of $1 \mathrm{~mW} / \mathrm{cm}^{2} 405 \mathrm{~nm}$ light, compared to white light or complete darkness, a MIC assay using $\mathrm{H}_{2} \mathrm{O}_{2}$ was carried out, and carotenoid content was measured. Results determined that the average $\mathrm{MIC}$ of $\mathrm{H}_{2} \mathrm{O}_{2}$ was significantly higher for the organism when cultured in lowlevel $\left(1 \mathrm{~mW} / \mathrm{cm}^{2}\right) 405 \mathrm{~nm}$ light compared to white light or complete darkness. This demonstrates that during growth in low-irradiance $405 \mathrm{~nm}$ light there is likely an increase in the expression of protective enzymes e.g. an increase in catalase enzymes which would act as hydrogen peroxide scavengers. An increase in catalase enzyme, KatA, following photodynamic inactivation of $S$. aureus (using blue light and exogenous porphyrins) was also demonstrated by Doselli et al. [31], which further suggest this enzyme is up-regulated to try to help protect the bacteria against oxidative stress.

The presence of the carotenoid staphyloxanthin was also found to be significantly lower in MSSA cultured in low-level $\left(1 \mathrm{~mW} / \mathrm{cm}^{2}\right) 405 \mathrm{~nm}$ light compared to when grown in white light or darkness. As carotenoid pigments have anti-oxidative properties, in particular for protecting bacteria against ${ }^{1} \mathrm{O}_{2}$ stress [32], you would expect MSSA cultivated in $1 \mathrm{~mW} / \mathrm{cm}^{2} 405 \mathrm{~nm}$ light to be more sensitive to subsequent high-intensity $405 \mathrm{~nm}$ light exposure, due to the lower levels of staphyloxanthin present. However, as tolerance is increased upon exposure to high-intensity $405 \mathrm{~nm}$ light, it is likely there is an up-regulation of other oxidative stress responses within

Table 2 Antibiotic susceptibility of MSSA and MRSA following sub-lethal exposure to $405 \mathrm{~nm}$ light

\begin{tabular}{|c|c|c|c|c|c|c|c|c|c|}
\hline \multirow[t]{2}{*}{ Antibiotic } & \multirow{2}{*}{$\begin{array}{l}\text { Conc } \\
(\mu \mathrm{g})\end{array}$} & \multicolumn{4}{|c|}{ Mean Diameter of Zone of Inhibition of MSSA (mm) } & \multicolumn{4}{|c|}{ Mean Diameter of Zone of Inhibition of MRSA (mm) } \\
\hline & & 0 & 5 & 10 & 15 & 0 & 5 & 10 & 15 \\
\hline Chloramphenicol & $25^{a}$ & $21 \pm 1.5$ & $21 \pm 0.8$ & $21 \pm 1.2$ & $21 \pm 0.8$ & $24 \pm 1.0$ & $24 \pm 1.1$ & $23 \pm 1.4$ & $23 \pm 1.1$ \\
\hline Ciprofloxacin & 5 & $22 \pm 1.2$ & $21 \pm 0.5$ & $22 \pm 0.7$ & $22 \pm 1.3$ & $26 \pm 0.6$ & $26 \pm 0.4$ & $26 \pm 1.0$ & $26 \pm 1.1$ \\
\hline Erythromycin & $5^{a}$ & $21 \pm 0.6$ & $21 \pm 0.6$ & $22 \pm 0.8$ & $21 \pm 0.4$ & $23 \pm 1.0$ & $22 \pm 0.8$ & $23 \pm 1.0$ & $23 \pm 1.2$ \\
\hline Fusidic Acid & 10 & $30 \pm 0.0$ & $30 \pm 0.8$ & $32 \pm 1.0^{*}$ & $31 \pm 1.8$ & $31 \pm 0.6$ & $30 \pm 0.5$ & $30 \pm 0.7$ & $30 \pm 0.9$ \\
\hline Gentamicin & 10 & $21 \pm 0.6$ & $21 \pm 0.5$ & $21 \pm 0.5$ & $20 \pm 0.5$ & $21 \pm 0.6$ & $21 \pm 0.5$ & $22 \pm 1.3$ & $23 \pm 0.6^{*}$ \\
\hline Mupirocin & $5^{a}$ & $28 \pm 0.6$ & $26 \pm 0.5^{*}$ & $28 \pm 1.4$ & $28 \pm 1.1$ & $26 \pm 0.6$ & $27 \pm 1.1$ & $26 \pm 1.2$ & $26 \pm 1.3$ \\
\hline Oxacillin & $5^{b}$ & $30 \pm 0.0$ & $29 \pm 0.9$ & $30 \pm 0.6$ & $30 \pm 0.9$ & $0 \pm 0.0$ & $0 \pm 0.0$ & $0 \pm 0.0$ & $0 \pm 0.0$ \\
\hline Rifampicin & 5 & $32 \pm 1.0$ & $32 \pm 0.7$ & $33 \pm 1.8$ & $34 \pm 0.6^{*}$ & $31 \pm 0.6$ & $30 \pm 0.7$ & $31 \pm 1.0$ & $31 \pm 0.9$ \\
\hline Tetracycline & $25^{a}$ & $28 \pm 1.2$ & $28 \pm 1.0$ & $28 \pm 1.4$ & $29 \pm 1.3$ & $27 \pm 1.0$ & $27 \pm 0.7$ & $27 \pm 1.0$ & $26 \pm 0.9$ \\
\hline Vancomycin & $5^{b}$ & $15 \pm 0.0$ & $14 \pm 0.7$ & $15 \pm 0.7$ & $15 \pm 0.5$ & $14 \pm 0.6$ & $15 \pm 0.6$ & $15 \pm 0.5$ & $14 \pm 0.5$ \\
\hline
\end{tabular}

Antibiotic susceptibility of methicillin-sensitive Staphylococcus aureus (MSSA) and methicillin-resistant Staphylococcus aureus (MRSA) after 5 , 10 and 15 sub-lethal exposures compared to equivalent non-sub-lethally exposed controls (0). Susceptibility was measured using Disc Diffusion Method

*indicates diameters of zones of inhibition that was significantly different to the equivalent non-sub-lethally exposed control $(P \leq 0.05)$. Each data point is a mean value $\pm \operatorname{SD}(n \geq 3)$

aDisc concentration is lower than that recommended by EUCAST

${ }^{\mathrm{b}}$ No disc concentration recommended by EUCAST 
the bacteria and that the carotenoid pigment provided protection against ROS during growth in low-intensity $405 \mathrm{~nm}$ light. Further experiments investigating superoxide dismutase, catalase activity could help to confirm this.

Although the inactivation achieved at $216 \mathrm{~J} / \mathrm{cm}^{2}$ (Fig. 4) was less when the bacteria had been pre-cultured in low-irradiance $\left(1 \mathrm{~mW} / \mathrm{cm}^{2}\right) 405 \mathrm{~nm}$ light, it is important to note that when exposed to a higher dose of $270 \mathrm{~J} / \mathrm{cm}^{2}$ complete $5 \log _{10}$ inactivation was still able to be achieved (Fig. 5b). It is likely that complete inactivation is still able to occur due the level of ROS produced being greater than the level that the basal bacterial oxidative stress defence systems are able to scavenge [30].

It is important to consider the possibility that bacteria may become less sensitive to high-irradiance $405 \mathrm{~nm}$ light after pre-culture in low-intensity, sub-lethal stress levels of $405 \mathrm{~nm}$ light, as this could have implications when violet-blue light is used to inactivate bacteria in nutritious environments where the bacteria are able to replicate, for example within wounds or surgical sites. In these cases it would be important to ensure a bactericidal dose was administered: if the dose administered or irradiance used is too low, the bacteria may not be completely inactivated and cause pathogenic organisms to potentially become more tolerant to subsequent applications of violet-blue light. Additionally, if the dose delivered is too low there may actually be an increase in population concentration, as it is thought visible light can encourage proliferation of microorganisms when used on nutrient rich areas such as wounds [28].

Further investigations were carried out to investigate if growth in low-intensity $405 \mathrm{~nm}$ light was selective for MSSA which was able to adapt to a greater level of oxidative stress. Results demonstrated that this was not the case, with the sensitivity of MSSA returning to a similar level of that when cultivated in complete darkness alone. These results additionally suggest that the increased tolerance to high-intensity $405 \mathrm{~nm}$ light is caused by an up-regulation in bacterial stress response rather than selection for violet-blue light tolerant colonies due to growth conditions.

Further work should be carried out to investigate the oxidative stress response following growth in low-intensity $405 \mathrm{~nm}$ light fully, such as the levels of superoxide dismutase, which has been previously shown to be up-regulated in S. aureus sensitive to PDI [33]. Additionally it is known that there is a heat shock protein cascade after PDI [30] and a study by St Denis et al. [34] demonstrated that $E$. coli exposed to external stress, before PDI showed a 2 $\log _{10}$ less reduction in bacterial inactivation compared to normal PDI inactivation levels. Therefore it would be interesting to investigate if there was a heat shock protein cascade during growth in $1 \mathrm{~mW} / \mathrm{cm}^{2}$ violet-blue light, and if this up-regulation of proteins before high-intensity exposure may contribute to the stress tolerance seen. Additionally, investigations should explore why the increased level of tolerance is not seen after repeated growth in the low-level stress conditions. However as the bacteria can still be completely inactivated, and as results indicated repeated growth in low-irradiance light is unlikely to be a selective process, MSSA should continue to be susceptible to high-irradiance $405 \mathrm{~nm}$ light after growth in the presence of a low-level stressor.

It is also important to note that the changes in susceptibility observed here are in response to the organisms being pre-cultured in low-level $405 \mathrm{~nm}$ light. This is unlikely to occur in non-proliferating bacteria, such as is the case with environmental contamination [17], as these organisms are stressed and not actively growing, thus up-regulation of stress responses is unlikely to occur, and actually when in a stationary stressed state, bacteria should become more susceptible to $405 \mathrm{~nm}$ light inactivation [35].

The next stage of this study was to investigate the likelihood of tolerance development when non-proliferating bacteria were repeatedly exposed to a sub-lethal dose of high-intensity $405 \mathrm{~nm}$ light. MSSA and MRSA were subjected to 15 exposure-subculture-exposure cycles to $60 \mathrm{~mW} / \mathrm{cm}^{2} 405 \mathrm{~nm}$ light, resulting in a dose of $108 \mathrm{~J} /$ $\mathrm{cm}^{2}$ per sub-lethal exposure. Results demonstrated no significant change in the level of inactivation achieved, with $1.2 \log _{10}$ and $1.4 \log _{10}$ inactivation achieved for MSSA and MRSA after 15 sub-lethal exposures respectively, compared to an initial $1.3 \log _{10}$ inactivation achieved for both.

The dose of $108 \mathrm{~J} / \mathrm{cm}^{2}$ was selected for exposure as it was shown to cause approximately $98 \%\left(1.6-1.8 \log _{10}\right)$ inactivation of the organism used in this study (Figs. 3 and 4). When compared to doses used in other studies to achieve similar levels of inactivation, this dose is somewhat greater $[6,7]$, however, the dose dependency will vary between studies, as it is specific to the light sources, the irradiances and the organisms used. LED arrays have variations in spectral output in terms of exact peak wavelength and bandwidth, and therefore this will affect the efficiency of bacterial inactivation. In addition, the overall doses used will vary depending on the output irradiance of the light source: the higher power the light source, the higher the irradiance, however, given that there will be a finite number of porphyrins per bacterial cell capable of photon absorption, there is likely to be a point at which the absorption of more photons would have little effect on the inactivation mechanism already in progress, therefore although more energy is being delivered, it may not translate into more effective kill.

Little other evidence has been documented regarding bacterial tolerance to $405 \mathrm{~nm}$ light. A short study by 
Guffey et al. [26] demonstrated that there was potential for $S$. aureus to become tolerant to a dose of $9 \mathrm{~J} / \mathrm{cm}^{2}$ $405 \mathrm{~nm}$ light, as following 5 repeated exposures there was a decrease in the kill rate seen. The study demonstrated an initial increase in kill rate from 32.92 to $59.49 \%$ after the 1 st to 4 th sub-lethal exposures, however kill rate subsequently declined, with only $18.04 \%$ kill after the 7 th repeated sub-lethal exposure, attributed to the development of resistance. These results are conflicting with those in this study, as our results indicate little change in bacterial response to $405 \mathrm{~nm}$ light inactivation following 15 sub-lethal exposures. In the present study, which used more than double the number of sub-lethal exposures and higher bacterial populations, natural variation in the level of inactivation occurred after repeated sub-lethal exposure, and this variation would be particularly apparent when using low population densities, as was the case in the study by Guffey et al. [26], so potentially further repeated sub-lethal exposures may have shown a subsequent increase in kill rate.

Additionally, in the present study $S$. aureus was repeatedly sub-lethally exposed whilst suspended in PBS. This allowed investigation of the sole effect that repeated antimicrobial violet-blue light exposure would have on bacterial cultures in a stationary, non-proliferating, state, representative of how bacteria would be found in the clinical environment. In the study by Guffey et al. [26], $S$. aureus was exposed to $405 \mathrm{~nm}$ light whilst seeded onto mannitol salt agar plates. Not only is mannitol known to be a ROS scavenger [36], in this scenario the bacteria were likely to be in a metabolic state, tolerating the high salt conditions $(7.5 \% \mathrm{NaCl})$ and fermenting mannitol, and therefore these processes may have affected the subsequent bacterial stress response to violetblue light. Consequently the increased tolerance seen may be more relative to results in the earlier phase of this study, where low-level exposure to $405 \mathrm{~nm}$ light in nutritious conditions resulted in higher dose requirements for complete inactivation.

Conversely, two studies which exposed Acinetobacter baumannii and P. aeruginosa to $415 \mathrm{~nm}$ light, under exposure conditions similar to this study, demonstrated no evidence of tolerance formation [20, 27]. Results are in keeping with study, with no tolerance to $415 \mathrm{~nm}$ light inactivation seen in $10^{8} \mathrm{CFU} / \mathrm{ml}$ populations of $P$. aeruginosa and $A$. baumannii after 10 repeated sub-lethal exposures to a dose of $36 \mathrm{~J} / \mathrm{cm}^{2}$ and $70.2 \mathrm{~J} / \mathrm{cm}^{2}$ respectively [20, 27]. These previous studies, along with the results in the present study, support the hypothesis that due to the unspecific mechanism of action and broad spectrum of intracellular targets, tolerance is not likely to occur.

Interestingly in the study by Zhang et al. [27] a significant increase in the sensitivity of $A$. baumannii was seen between the 1 st exposure (4.52 $\log _{10}$ reduction) and the 10th exposure (6.28 $\log _{10}$ reduction) and inactivation curves revealed an increase in inactivation between 1, 6 and 9 sub-lethal exposures. These results were thought to indicate that a favourable mutation had occurred, increasing bacterial susceptibly to violet-blue light inactivation [27]. To investigate if this phenomenon would also occur in Staphylococcus aureus, the inactivation kinetics of surviving isolates after 5, 10 and 15 sub-lethal exposures were determined and all followed similar trends. Although these results do not indicate an increase in sensitivity of MSSA and MRSA to $405 \mathrm{~nm}$ light after repeated sublethal exposure, they do demonstrate consistent Staphylococcal sensitivity to high-irradiance $405 \mathrm{~nm}$ light and further supports the hypothesis that tolerance to $405 \mathrm{~nm}$ light inactivation in unlikely. However, the potential for tolerance should be evaluated in other microorganisms normally susceptible to $405 \mathrm{~nm}$ light inactivation, including multidrug resistant organisms which are currently a great problem in healthcare settings [37, 38].

Antibiotic susceptibility was also analysed to ensure that repeated $405 \mathrm{~nm}$ light exposure did not give rise to 'stress hardening', whereby as a result of continued exposure to this sub-lethal stress the bacteria would be able to adapt and develop protection mechanisms against other applied stresses [39, 40]. Little significant variation was seen with the antibiotic susceptibility for both $S$. aureus strains. Although a slight decrease in susceptibility of MSSA to mupirocin was noted after 5 sublethal exposures (an observation which was not observed following increased sub-lethal exposures to 10 or $15 \mathrm{cy}$ cles), it is worth noting that although the concentration of mupirocin antibiotic disc $(5 \mu \mathrm{g})$ was below the recommended concentration used by EUCAST $(200 \mu \mathrm{g})$, the zone of inhibition measured was still far greater $(26 \mathrm{~mm})$ than the EUCAST breakpoints for resistance $(18 \mathrm{~mm})$. Therefore, indicating that although significantly different to the initial non sub-lethally exposed MSSA, after 5 sub-lethal exposures MSSA is bacteria is still sensitive to mupirocin.

Furthermore, to the best of our knowledge these are the first results comparing repeated sub-lethal $405 \mathrm{~nm}$ light exposure and antibiotic susceptibility, and they indicate that sub-lethal exposure is unlikely to result in the development of antibiotic resistance. These findings are further supported by those of Pedigo et al. [23], who demonstrated no antibiotic resistance occurred in MSSA after 25 repeat exposures to PDI, using a methylene blue photosensitizer and $670 \mathrm{~nm}$ light, compared to antibiotic resistance in MSSA after only 11 exposures to a $1 \mu \mathrm{g} / \mathrm{ml}$ oxacillin disk. Similarly, Grinholc et al. [41] found no change in antibiotic susceptibility in MRSA before and after exposure to PDI (using protoporphyrin diarginate and $624 \mathrm{~nm}$ light) with the 26 different antibiotics tested. 
Future studies should involve a greater range of commonly used antibiotics and broth microdilution studies should be carried out to enable the quantification of the MIC of each antibiotic before and after sub-lethal exposure. However, overall these results indicate repeated sub-lethal exposure to $405 \mathrm{~nm}$ light is unlikely to affect $S$. aureus susceptibility to antibiotics, and supports the practical application of $405 \mathrm{~nm}$ light for decontamination applications within in the clinical environment [42].

This study was designed to generate fundamental microbiological information with regards to the potential for the development of bacterial tolerance to $405 \mathrm{~nm}$ light. To investigate this, S. aureus was exposed to highirradiance light whilst in suspension, following either growth in low-level blue light stress conditions or previous sub-lethal exposures to $405 \mathrm{~nm}$ light. As discussed earlier, the $405 \mathrm{~nm}$ light levels used in the present study permitted establishment of the fundamental responses of the light-exposed bacteria. There is however, interest in utilising this antimicrobial technology for practical decontamination applications and it will therefore be important for future studies to progress investigations towards more clinically-relevant scenarios. This could include repeated exposure of bacteria on inert surfaces with low-irradiance $405 \mathrm{~nm}$ light more representative of levels which would be used for environmental decontamination $\left(<1 \mathrm{~mW} / \mathrm{cm}^{2}\right)$ [15-18], or repeated exposure of organisms on tissue models using higher irradiance light, more suited for representation of wound treatments [12]. It would also be important to investigate if there are any differences when bacteria are dried onto clinical surfaces compared to when suspended in biological fluids such as blood and secretions. A previous study by Murdoch et al. [43], also demonstrated that bacteria can be more susceptible to inactivation when exposed whilst dried onto surfaces and in a desiccated state, and it is reasonable to consider that this increased susceptibility when on surfaces is likely to reduce the likelihood of persistent survival and tolerance/resistance. In addition, if the bacteria are present in biological fluids or embedded in a biological matrix then the inactivation effect could be enhanced by the excitation of photosensitive components present in the biological fluids or matrix (which accelerates the production of ROS) [10, 11]. Conversely it must also be considered that inactivation efficacy of the $405 \mathrm{~nm}$ light could be hindered by the opaque transmission properties of the suspending fluid/matrix. Clearly much more research is required to understand not only the tolerance response of bacteria to $405 \mathrm{~nm}$ light but also the complex interplay between physico-chemical and environmental factors that can impact on the efficacy of the light induced inactivation in real clinical settings.
Finally, it would also be important to establish the influence of strain variance on the potential for tolerance. Although comparisons were made between methicillin sensitive and resistant strains of $S$. aureus other studies have demonstrated that photodynamic inactivation and violet-light exposure can vary between exposed strains of the same organisms $[28,44]$.

\section{Conclusions}

In conclusion, the results in this study provide novel fundamental information surrounding the potential for tolerance development in proliferating $S$. aureus cultivated in lowlevel $405 \mathrm{~nm}$ light. Additionally no evidence of tolerance was generated in non-proliferating antibiotic sensitive and resistant organisms, following repeated sub-lethal exposure. Repeated sub-lethal exposure was also shown to have little effect on inactivation kinetics or antibiotic susceptibility. Whilst previous studies have established that violet-blue light can be safely used for continuous decontamination in occupied environments $[15,16,18]$, wound decontamination in mouse models [13, 20, 27, 45], and that it can inactivate a wide range of microorganisms [5-11], our current findings indicate that in fundamental studies using high-intensity light irradiances, bacterial tolerance is unlikely to occur even after repeated use.

These proof-of-principle results offer additional evidence towards the effective use of antimicrobial $405 \mathrm{~nm}$ light for decontamination applications within the clinical setting, however further work is needed to translate these findings to use lower, more clinically-relevant irradiance levels and/or longer duration exposures, relevant for applications such as environmental and wound decontamination.

\section{Abbreviations \\ ${ }^{1} \mathrm{O}_{2}$ : Singlet oxygen; CFU: Colony forming units; EMRSA - 15/MRSA: Epidemic methicillin-sensitive Staphylococcus aureus-15; FHWM: Full width at half maximum; $\mathrm{H}_{2} \mathrm{O}_{2}$ : Hydrogen peroxide; LED: Light emitting diode; $\mathrm{MH}$ : Mueller- hinton; MIC: Minimum inhibitory concentration; MSSA: Methicillin-sensitive Staphylococcus aureus; NA: Nutrient agar; NB: Nutrient broth; PBS: Phosphate buffered saline; PDI: Photodynamic inactivation; ROS: Reactive oxygen species; SD: Standard deviation; UV: Ultraviolet}

\section{Acknowledgements}

The authors wish to thank the Scottish Reference Laboratory, Glasgow (SMiRL) who supplied a clinical isolate of EMRSA-15. The authors also wish to thank Mr. Daniel Irving for providing assistance with graphic design and The Robertson Trust for their support.

\section{Funding}

RMT would like to thank the Scottish Infection Research Network and Chief Scientist Office for their funding support through a Doctoral Fellowship Award, CSO Reference: SIRN/DTF/13/02. The funders had no role in study design, data collection, analysis and interpretation or in the writing of the manuscript.

Availability of data and materials

All data generated or analysed during this study are included in this published article, and the datasets used are available from the corresponding author on reasonable request. 


\section{Authors' contributions}

RMT collected, analysed and interpreted the data regarding bacterial tolerance and was the main author of the manuscript. MM also analysed and interpreted the data and contributed to the writing of the manuscript. All authors helped to design the study, and read and approve the final manuscript.

\section{Ethics approval and consent to participate}

N/A

\section{Consent for publication}

N/A

\section{Competing interests}

The authors declare that they have no competing interests.

\section{Publisher's Note}

Springer Nature remains neutral with regard to jurisdictional claims in published maps and institutional affiliations.

\section{Author details}

'The Robertson Trust Laboratory for Electronic Sterilisation Technologies (ROLEST), Department of Electronic \& Electrical Engineering, University of Strathclyde, Glasgow, UK. ${ }^{2}$ Department of Biomedical Engineering, University of Strathclyde, Glasgow, UK. ${ }^{3}$ Department of Clinical Microbiology, Glasgow Royal Infirmary, Glasgow, UK.

Received: 6 June 2017 Accepted: 18 September 2017 Published online: 29 September 2017

\section{References}

1. Cosgrove SE. The relationship between antimicrobial resistance and patient outcomes: mortality, length of hospital stay, and health care costs. Clin Infect Dis. 2006:42:582-9.

2. Hamblin MR, Hasan T. Photodynamic therapy: a new antimicrobial approach to infectious disease? Photochem Photobiol Sci. 2004;3:436-50.

3. Maclean M, MacGregor SJ, Anderson JG, Woolsey G. High-intensity narrowspectrum light inactivation and wavelength sensitivity of Staphylococcus aureus. FEMS Microbiol Lett. 2008;285:227-32.

4. Maclean M, MacGregor SJ, Anderson JG, Woolsey GA. The role of oxygen in the visible-light inactivation of Staphylococcus aureus. J Photochem Photobiol B. 2008;92:180-4

5. Guffey JS, Wilborn J. In vitro bactericidal effects of 405-nm and 470-nm blue light. Photomed Laser Surg. 2006;24:684-8.

6. Maclean M, MacGregor SJ, Anderson JG, Woolsey G. Inactivation of bacterial pathogens following exposure to light from a 405-nanometer light-emitting diode array. Appl Environ Microbiol. 2009;75:1932-7.

7. Maclean M, Murdoch LE, MacGregor SJ, Anderson JG. Sporicidal effects of high-intensity $405 \mathrm{~nm}$ visible light on endospore-forming bacteria. Photochem Photobiol. 2013;89:120-6.

8. McKenzie K, Maclean M, Timoshkin IV, Endarko E, MacGregor SJ, Anderson JG. Photoinactivation of bacteria attached to glass and acrylic surfaces by $405 \mathrm{~nm}$ light: potential application for biofilm decontamination. Photochem Photobiol. 2013:89:927-35.

9. Murdoch LE, McKenzie K, Maclean M, MacGregor SJ, Anderson JG. Letha effects of high intensity violet 405-nm light on Saccharomyces cerevisiae, Candida albicans and on dormant and germinating spores of Aspergillus niger. Fungal Biol. 2013:117:519-27.

10. Tomb RM, Maclean M, Herron PR, Hoskisson PA, MacGregor SJ, Anderson JG. Inactivation of Streptomyces phage $\phi C 31$ by $405 \mathrm{~nm}$ light: requirement for exogenous photosensitizers? Bacteriophage. 2014;4:e32129.

11. Tomb RM, Maclean M, Coia JE, Graham E, McDonald M, Atreya CD, MacGregor SJ, Anderson JG. New proof-of-concept in viral inactivation: virucidal efficacy of $405 \mathrm{~nm}$ light against feline calicivirus as a model for norovirus decontamination. Food Environ Virol. 2017:9: 159-67.

12. McDonald R, MacGregor SJ, Anderson JG, Maclean M, Grant MH. Effect of 405-nm high-intensity narrow-spectrum light on fibroblast-populated collagen lattices: an in vitro model of wound healing. J Biomed Optic. 2011;16:048003
13. Dai T, Gupta A, Huang YY, Yin R, Murray CK, Vrahas MS, Sherwood ME, Tegos GP, Hamblin MR. Blue light rescues mice from potentially fatal Pseudomonas aeruginosa burn infection: efficacy, safety, and mechanism of action. Antimicrob Agents Chemother. 2013;57:1238-45.

14. Ramakrishnan P, Maclean M, MacGregor SJ, Anderson JG, Grant MH. Cytotoxic responses to $405 \mathrm{~nm}$ light exposure in mammalian and bacterial cells: involvement of reactive oxygen species. Toxicol in Vitro. 2016;33:54-62.

15. Maclean M, Macgregor SJ, Anderson JG, Woolsey GA, Coia JE, Hamilton K, Taggart I, Watson SB, Thakker B, Gettinby G. Environmental decontamination of a hospital isolation room using high-intensity narrow-spectrum light. J Hosp Infect. 2010;76:247-51.

16. Maclean M, Booth MG, Anderson JG, MacGregor SJ, Woolsey GA, Coia JE, Hamilton K, Gettinby G. Continuous decontamination of an intensive care isolation room during patient occupancy using $405 \mathrm{~nm}$ light technology. J Infect Prevent. 2013:14:176-81.

17. Maclean M, McKenzie K, Anderson JG, Gettinby G, MacGregor SJ. 405 nm light technology for the inactivation of pathogens and its potential role for environmental disinfection and infection control. J Hosp Infect. 2014;88:1-11.

18. Bache SE, Maclean M, MacGregor SJ, Anderson JG, Gettinby G, Coia JE, Taggart I. Clinical studies of the high-intensity narrow-spectrum light environmental decontamination system [HINS-light EDS], for continuous disinfection in the burn unit inpatient and outpatient settings. Burns. 2012;38:69-76.

19. Moorhead S, Maclean M, Coia JE, MacGregor SJ, Anderson JG. Synergystic efficacy of $405 \mathrm{~nm}$ light and chlorinated disinfectants for enhanced decontamination of Clostridium difficile spores. Anaerobe. 2016;37:72-7.

20. Amin RM, Bhayana B, Hamblin MR, Dai T. Antimicrobial blue light inactivation of Pseudomonas aeruginosa by photo-excitation of endogenous porphyrins: In vitro and in vivo studies. Lasers Surg Med. 2016; https://doi.org/10.1002//sm.22474.

21. Tavares A, Carvalho C, Faustino MA, Neves MG, Tomé JP, Tomé AC, Cavaleiro JAS, Cunha Â, Gomes NCM, Alves E, Almeida A. Antimicrobial photodynamic therapy: study of bacterial recovery viability and potential development of resistance after treatment. Mar Drugs. 2010;8:91-105.

22. Lauro FM, Pretto P, Covolo L, Jori G, Bertoloni G. Photoinactivation of bacterial strains involved in periodontal diseases sensitized by porphycenepolylysine conjugates. Photochem Photobiol Sci. 2002;1:468-70.

23. Pedigo LA, Gibbs AJ, Scott RJ, Street CN. Absence of bacterial resistance following repeat exposure to photodynamic therapy. Proc SPIE. 2009:7380:73803H-1.

24. Giuliani F, Martinelli M, Cocchi A, Arbia D, Fantetti L, Roncucci G. In vitro resistance selection studies of $\mathrm{RLP068/Cl}$, a new Zn[II] phthalocyanine suitable for antimicrobial photodynamic therapy. Antimicrob Agents Chemother. 2010;54:637-42.

25. Bartolomeu M, Rocha S, Cunha Â, Neves MGPMS, Faustino MA, Almeida A. Effect of photodynamic therapy on the virulence factors of Staphylococcus aureus. Front Microbiol. 2016:7:267.

26. Guffey JS, Payne W, Jones T, Martin K. Evidence of resistance development by Staphylococcus aureus to an in vitro, multiple stage application of $405 \mathrm{~nm}$ light from a supraluminous diode array. Photomed Laser Surg. 2013;31:179-82.

27. Zhang Y, Zhu Y, Gupta A, Huang Y, Murray CK, Vrahas MS, Sherwood ME, Baer DG, Hamblin MR, Dai T. Antimicrobial blue light therapy for multidrugresistant Acinetobacter baumannii infection in a mouse burn model: implications for prophylaxis and treatment of combat-related wound infections. J Infect Dis. 2014:209:1963-71.

28. Lipovsky A, Nitzan Y, Friedmann H, Lubart R. Sensitivity of Staphylococcus aureus strains to broadband visible light. Photochem Photobiol. 2009:85:255-60.

29. Matuschek E, Brown DFJ, Kahlmeter G. Development of the EUCAST disk diffusion antimicrobial susceptibility testing method and its implementation in routine microbiology laboratories. Clin Microbiol Infect. 2014;20:0255-66.

30. Maisch T. Resistance in antimicrobial photodynamic inactivation of bacteria. Photochem Photobiol Sci. 2015:14:1518-26.

31. Dosselli R, Millioni R, Puricelli L, Tessari P, Arrigoni G, Franchin C, Segalla A, Teardo E, Reddi E. Molecular targets of antimicrobial photodynamic therapy identified by a proteomic approach. J Proteome. 2012;77:329-43.

32. Liu GY, Essex A, Buchanan JT, Datta V, Hoffman HM, Bastian JF, Fierer J, Nizet V. Staphylococcus aureus golden pigment impairs neutrophil killing and promotes virulence through its antioxidant activity. J Exp Med. 2005:202:209-15.

33. Nakonieczna J, Michta E, Rybicka M, Grinholc M, Gwizdek-Wiśniewska A, Bielawski KP. Superoxide dismutase is upregulated in Staphylococcus aureus following protoporphyrin-mediated photodynamic inactivation and does not directly influence the response to photodynamic treatment. BMC Microbiol. 2010;10:323. 
34. St Denis TG, Huang L, Dai T, Hamblin MR. Analysis of the bacterial heat shock response to photodynamic therapy-mediated oxidative stress. Photochem Photobiol. 2011;87:707-13.

35. McKenzie K, Maclean M, Timoshkin IV, MacGregor SJ, Anderson JG. Bactericidal effect of $405 \mathrm{~nm}$ light on Escherichia coli and Listeria monocytogenes in the presence of sub-lethal stress. Int J Food Microbiol. 2014;170:91-8.

36. Santos AL, Gomes NCM, Henriques I, Almeida A, Correia A, Cunha Â. Contribution of reactive oxygen species to UV-B-induced damage in bacteria. J Photochem Photobiol B Biol. 2012;117:40-6.

37. Pendleton JN, Gorman SP, Gilmore BF. Clinical relevance of the ESKAPE pathogens. Expert Rev Anti-Infect Ther. 2013;1 1:297-308.

38. Vasoo S, Barreto $\mathrm{JN}$, Tosh PK. Emerging issues in gram-negative bacterial resistance: an update for the practicing clinician. Mayo Clin Proc. 2015;90:395-403.

39. Koutsoumanis KP, Kendall PA, Sofos JN. Effect of food processing related stresses on acid tolerance of Listeria monocytogenes. Appl Environ Microbiol. 2003;69:514-7516.

40. McMahon MA, Xu J, Moore JE, Blair IS, McDowell DA. Environmental stress and antibiotic resistance in food-related pathogens. Appl Environ Microbiol. 2007;73:211-7.

41. Grinholc M, Szramka B, Olender K, Graczyk A. Bactericidal effect of photodynamic therapy against methicillin-resistant Staphylococcus aureus strain with the use of various porphyrin photosensitizers. Acta Biochim Pol. 2007;54:665-70

42. Boyce JM. Modern technologies for improving cleaning and disinfection of environmental surfaces in hospitals. Antimicrob Res Infect Cont. 2016;5:10.

43. Murdoch LE, Maclean M, Endarko E, MacGregor SJ, Anderson JG. Bactericidal effects of $405 \mathrm{~nm}$ light exposure demonstrated by inactivation of Escherichia, Salmonella, Shigella, Listeria, and Mycobacterium species in liquid suspensions and on exposed surfaces. Sci World J. 2012;2012:137805.

44. Halstead FD, Thwaite JE, Burt R, Laws TR, Raguse M, Moeller R, Webber MA, Oppenheim BA. Antibacterial activity of blue light against nosocomial wound pathogens growing planktonically and as mature biofilms. Appl Environ Microbiol. 2016:82:4006-16.

45. Dai T, Gupta A, Huang YY, Sherwood ME, Murray CK, Vrahas MS, Kielian T, Hamblin MR. Blue light eliminates community-acquired methicillin-resistant Staphylococcus aureus in infected mouse skin abrasions. Photomed Laser Surg. 2013;11:531-8.

\section{Submit your next manuscript to BioMed Central and we will help you at every step:}

- We accept pre-submission inquiries

- Our selector tool helps you to find the most relevant journal

- We provide round the clock customer support

- Convenient online submission

- Thorough peer review

- Inclusion in PubMed and all major indexing services

- Maximum visibility for your research

Submit your manuscript at www biomedcentral.com/submit

) Biomed Central 